\title{
Unbaked materials from mixtures of waste sludge of a water purification plant, fly ash, and water glass
}

\author{
Do Quang Minh ${ }^{1,2,{ }^{*}, \text { Huynh Ngoc Minh }}{ }^{1,2}$, Nguyen Vu Uyen Nhi ${ }^{1,2}$
}

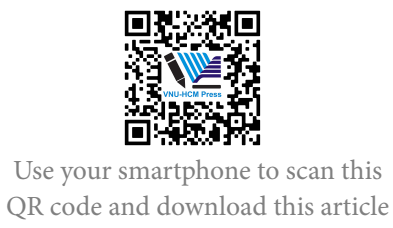

${ }^{l}$ Department of Silicate Materials, Faculty of Materials Technology, Ho Chi Minh City University of Technology (HCMUT), 268 Ly Thuong Kiet Street, District 10, Ho Chi Minh City, Vietnam

${ }^{2}$ Vietnam National University Ho Chi Minh City, Linh Trung Ward, Thu Duc District, Ho Chi Minh City, Vietnam

\section{Correspondence}

Do Quang Minh, Department of Silicate Materials, Faculty of Materials Technology, Ho Chi Minh City University of Technology (HCMUT), 268 Ly Thuong Kiet Street, District 10, Ho Chi Minh City, Vietnam

Vietnam National University Ho Chi Minh City, Linh Trung Ward, Thu Duc District, Ho Chi Minh City, Vietnam

Email: mnh_doquang@hcmut.edu.vn

History

- Received: 10-8-2020

- Accepted: 27-01-2021

- Published: 15-02-2021

DOI : 10.32508/stdjet.v4i1.754

\section{Check for updates}

\section{Copyright}

(c) VNU-HCM Press. This is an openaccess article distributed under the terms of the Creative Commons Attribution 4.0 International license.

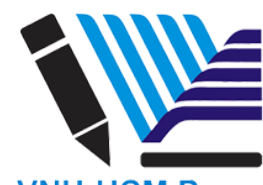

VNU-HCM Press

\begin{abstract}
In water purification plants, a large area of urban land is using to store waste sludge (WS). The waste sludge from water filtration plants is aluminosilicate, which can form a geopolymer. However, the waste sludge has low alkaline activity, so it must be used in combination with fly ash (FA) to create geopolymer products. Fly ash is a solid waste containing amorphous silica and it has high alkaline activity, so that it is suitable for treatment by the geopolymer method. The geopolymerization of waste sludge from water purification plants is a relatively new method. The geopolymer is a binder formed by the chemical reaction between aluminosilicate materials and alkaline activated solutions. The alkaline activated solution used in these experiments was water glass (WG). The water glass is the solution of sodium silicate $\left(\mathrm{Na}_{2} \mathrm{O} . n \mathrm{niO}_{2}\right)$ dissolved in water. The research results of geopolymer materials from the mixture of fly ash, the waste sludge of Thu Duc water purification plant in Ho Chi Minh City (Vietnam), and water glass (WG) were introduced in this study. The activated $\mathrm{Al}_{2} \mathrm{O}_{3}$ and $\mathrm{SiO}_{2}$ oxides in the fly ash and the waste sludge can be dissolved in the water glass and polymerized into a geopolymer material. The test samples had pressed at a high pressure of $225 \mathrm{MPa}$ to form cylindrical ones weighing approximately 3 grams, height about $18 \mathrm{~mm}$, and $10 \mathrm{~mm}$ in diameter. These samples were then cured at $110^{\circ} \mathrm{C}$ for 24 hours and at room temperature $\left(30 \pm 5^{\circ} \mathrm{C}\right)$. The methods of Fourier infrared spectroscopy (FTIR) and scanning electron microscope (SEM) had used to detect the microscopic structure and geopolymer bond formation of the samples. The compressive strength of the tested samples at 28 days old was higher than 3.5 $\mathrm{MPa}$, the $\mathrm{pH}$ was less than 12.5, meeting the Vietnamese National Standards for unbaked materials (TCVN 6477:2016) and National Technical Regulation on environmental impact (QCVN 50:2013 / BTNMT), respectively. The results show a new approach of solidifying the waste sludge for further applications such as the manufacture of geopolymer concretes or landfill materials.

Key words: unbaked material, fly ash (FA), waste sludge (WS), water glass (WG), alkaline activated solution, geopolymer
\end{abstract}

\section{INTRODUCTION}

Waste sludge (WS) from water purification plants is composed mainly of aluminosilicate. The WS is usually treated by methods as landfills, making ceramic bricks $^{1-3}$... However, due to the areas of landfill sites, WS management is a growing global problem ${ }^{2}$. It is necessary to study the treatment of WS by new methods. In recent years, the treatment of the WS by polymerization is also being interested in many studies $^{4-6}$.

Geopolymer is a binder formed by the chemical reaction between aluminosilicate materials and alkaline activated solutions. The alkaline activated solutions are composed of strongly alkaline solutions such as sodium hydroxide $(\mathrm{NaOH})$, potassium hydroxide $(\mathrm{KOH})$, soda ash $\left(\mathrm{Na}_{2} \mathrm{CO}_{3}\right)$, calcium hydroxide $\left(\mathrm{Ca}(\mathrm{OH})_{2}\right)$, and water glass (WG: $\left.\mathrm{Na}_{2} \mathrm{O} \cdot \mathrm{nSiO}_{2} \cdot \mathrm{mH}_{2} \mathrm{O}\right)^{2,3}$. Fly ash (FA), silica fume, kiln slag, and metakaolin are the industrial wastes used as raw materials to produce the geopolymers ${ }^{4-7}$. Unbaked materials made from WS of the Thu Duc water purification plant, Vinh Tan fly ash, and the WG are introduced in this research.

Sodium silicate is a generic name for chemical compounds with the formula $\mathrm{Na}_{2} \mathrm{O}: \mathrm{nSiO}_{2}$ (molar ratio $\mathrm{n} \sim 1 \div 3.75$ named module of sodium silicate) and soluble in water with various amounts. The solution of the sodium silicate in water is called water glass or liquid glass. Activated $\mathrm{Al}_{2} \mathrm{O}_{3}$ and $\mathrm{SiO}_{2}$ oxides in aluminosilicate can be dissolved in an alkaline solution to form a similar bonding circuit of a WG. The bonding circuit is $\mathrm{M}\left\{-\left(\mathrm{SiO}_{2}\right)_{z}-\mathrm{AlO}_{2}\right\}_{n}$. wH $\mathrm{wH}_{2} \mathrm{O}$, wherein $\mathrm{M}$ is a cation such as $\mathrm{K}^{+}, \mathrm{Na}^{+}, \mathrm{Ca}^{2+}$, and "n" is a degree of polycondensation, $\mathrm{z}$ is $1,2,3$ [8]. When dehydrated, the WG condenses to form a gel-like polymer circuit with the features of poly (sialate) $\mathrm{M}_{n}-(-\mathrm{Si}-$ $\mathrm{O}-\mathrm{Al}-\mathrm{O}-)_{n}$ and poly (sialate - siloxo $) \mathrm{M}_{n}-(-\mathrm{Si}$ $\mathrm{O}-\mathrm{Al}-\mathrm{O}-\mathrm{Si}-\mathrm{O}-)_{n}{ }^{7-9}$. For increasing the rate of 
condensation, the unbaked materials can be applied to the treatments in the atmosphere by drying at 65 $110^{\circ} \mathrm{C}^{8,10}$ or using microwave energy ${ }^{11}$.

When using WS to fabricate unburned materials by the geopolymer method, due to the weak alkaline activity of the WS, the substances with better alkaline activity such as FA, silica fume often need to be mixed ${ }^{1}$. The use of strongly alkaline substances influences the surroundings, first of all, is $\mathrm{pH}$. Using WG binders can reduce the impact of environmental $\mathrm{pH}$ less than using $\mathrm{NaOH}, \mathrm{KOH}$. Furthermore, WS is relatively inexpensive, easy to use, and non-toxic.

This research presented some results on the physicomechanical properties and environmental $\mathrm{pH}$ effects of unburned materials made from WS, FA, and WG binder. The bonding and microstructure of the materials had to be studied by Fourier infrared spectroscopy (FTIR) and scanning electron microscope (SEM).

\section{EXPERIMENTAL METHODS}

\section{Raw materials}

The raw materials are WS from Thu Duc water purification plant, FA from Vinh Tan thermal power plant, alkaline activator solution is water glass WG. The chemical composition of the raw materials was determined using the X-ray Fluorescence method.

The alkaline activity of WS depends on the solubility of the oxides in alkaline solution with different concentrations. The amount of activated $\mathrm{SiO}_{2}, \mathrm{Al}_{2} \mathrm{O}_{3}$, and $\mathrm{Fe}_{2} \mathrm{O}_{3}$ oxides of the WS dissolved in $\mathrm{NaOH}$ solution was determined in referring to Vietnamese $\mathrm{Na}$ tional Standards (TCVN 7572-19: 2006) ${ }^{9}$.

The mixing ratio of FA/(FA+WS) changed from 10-70 (\% by weight). To achieve the compressive strength of at least 3.5 $\mathrm{MPa}$ (refer to Vietnamese National Standards TCVN 6477:2016 ${ }^{12}$ ) and to reduce the amount of alkali discharged into the environment (National Technical Regulation QCVN 50:2013/BT$\mathrm{NMT}^{13}$ ), the chosen alkaline activated solution was WG. The mixing ratios of WG and the solid (FA + WS) mixture were $6,8,10,12$, and 14 (\% mass fraction). The (FA + WS) mixture and WG must be thoroughly mixed before being formed by pressing.

\section{Forming}

The weight of each test sample was $3 \mathrm{~g}$ and pressed in a steel mold to form a cylindrical specimen with height $\mathrm{h}=(18 \pm 1) \mathrm{mm}$, diameter $\mathrm{d}=(10 \pm 0.2)$ $\mathrm{mm}$ (Figure 1). The samples had pressed at $225 \mathrm{MPa}$ pressure, and the moisture content of the mixture was about $7-8 \%$. This pressure value was the parameter for the cohesion and high density of shaped samples. As the pressure increases further, the sample density hardly increases anymore ${ }^{11}$. After forming, the samples had cured under two different conditions: 1 . At room temperature (average about $(30 \pm 5)^{\circ} \mathrm{C}$ ) for 24 hours, and 2. In a Venticell laboratory dryer (MMM Medcenter Einrichtungen $\mathrm{GmbH}$ ) at $110^{\circ} \mathrm{C}$ for 24 hours. Then, both sample groups were cured at room temperature $(30 \pm 5)^{\circ} \mathrm{C}$ at the same time until the determining properties. The properties identified were volumetric density and compressive strength.

\section{Determination of the properties}

The physico-mechanical properties of the specimens were determined after 28 days of curing. This is the time that the specimen weight has been not changed, the properties were considered stable ${ }^{11}$. Volumetric density was determined by equation $\mathrm{d}=\mathrm{m} / \mathrm{V}$ (therein $\mathrm{m}$ is the weight of the sample and $\mathrm{V}$ is its volume, calculated by $\mathrm{V}=\pi \mathrm{d}^{2} \mathrm{~h} / 4$. Compressive strength was determined by the DTU-900 MNH equipment (loading speed $3 \mathrm{kN} / \mathrm{min}$ ). Chemical composition was analyzed using the X-ray Fluorescence method by the XRF- Thermo ARL ADVANT'X spectrometer. The $\mathrm{pH}$ was determined daily during curing time of 28 days according to ASTM D3987-12 (2020) ${ }^{14}$ with the Hanna Instruments HI221 pH meter.

The sample group with the best mechanical strength (10\% WG) was selected for FTIR analysis (Bruker Tensor 27 spectrometer) and the microstructure was analyzed by scanning electron microscopy (Hitachi S4800 FE-SEM) for determination of bonds in the sample.

\section{THE RESULTS AND DISCUSSIONS}

Chemical composition of raw materials, solubility of oxides in alkaline solution and SEM of WS, FA.

WS was taken from the Thu Duc water purification plant (Ho Chi Minh City, Vietnam), FA was from Vinh Tan thermal power plant (Binh Thuan province, Vietnam), and WG was a commercial product. Chemical composition of raw materials is shown in Table 1. The amount of oxides dissolved in $\mathrm{NaOH}$ solution with different concentrations is shown in Table 2.

From the data in Table 1, the module of the WG $\left(\mathrm{Na}_{2} \mathrm{O}: \mathrm{nSiO}_{2}, \mathrm{n}\right.$ : molar ratio) was calculated: $\mathrm{n}=$ 1.74 .

The results show that the dominant dissolved component was $\mathrm{Al}_{2} \mathrm{O}_{3}$.

Scanning electron microscope (SEM) images of WS and FA are shown in Figure 2. 


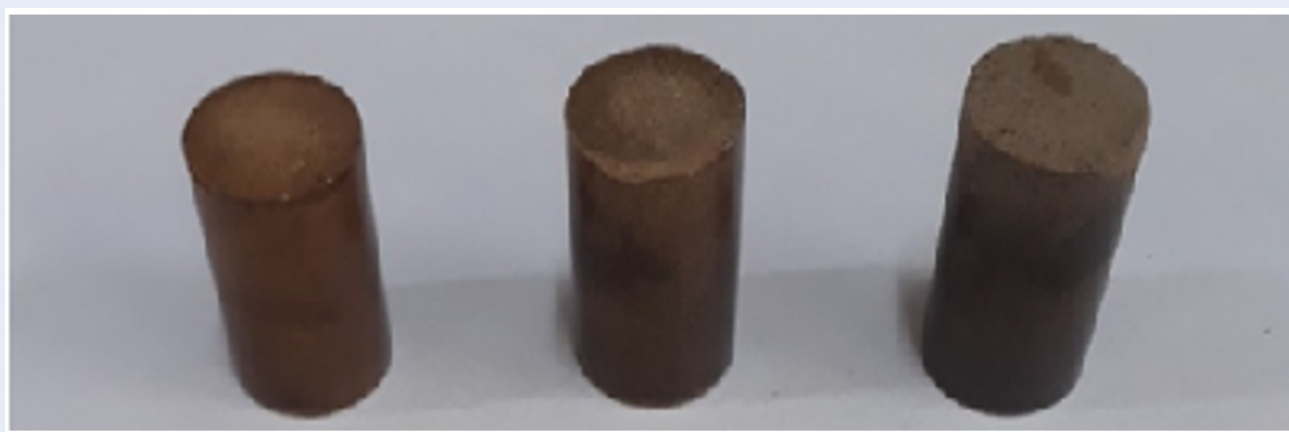

Figure 1: Image of the samples

Table 1: Chemical composition of raw materials (\% wt.)

\begin{tabular}{lccccccccc}
\hline Oxides & $\mathrm{SiO}_{2}$ & $\mathrm{Fe}_{2} \mathrm{O}_{3}$ & $\mathrm{Al}_{2} \mathrm{O}_{3}$ & $\mathrm{TiO}_{2}$ & $\mathrm{~K}_{2} \mathrm{O}$ & $\mathrm{CaO}$ & $\mathrm{Na}_{2} \mathrm{O}$ & Others & LOI $^{*}$ \\
FA & 48.93 & 11.22 & 26.19 & 1.38 & 6.94 & 1.52 & - & 2.27 & 1.55 \\
WS & 28.14 & 27.81 & 20.65 & 2.64 & 1.30 & 1.55 & - & 1.30 & 16.54 \\
WG & 52.67 & 0.04 & 1.59 & - & - & - & 31.24 & 0.46 & 14.00 \\
\hline
\end{tabular}

$\left(^{*}\right)$ Loss on ignition at $1000^{\circ} \mathrm{C}$.

Table 2: $\mathrm{SiO}_{2}, \mathrm{Al}_{2} \mathrm{O}_{3}$, and $\mathrm{Fe}_{2} \mathrm{O}_{3}$ oxides (\% wt.) of WS dissolved in $\mathrm{NaOH}$ solution

\begin{tabular}{lcccccccccc}
\hline Amount of dissolved oxides (\% wt.) & \multicolumn{7}{c}{ Concentration of NaOH solution (M) } \\
& 1 & 2 & 3 & 4 & 5 & 6 & 7 & 8 \\
$\mathrm{SiO}_{2}$ & 0.46 & 0.71 & 0.90 & 1.10 & 1.35 & 1.67 & 1.89 & 2.06 & 2.24 \\
$\mathrm{Al}_{2} \mathrm{O}_{3}$ & 1.56 & 3.08 & 3.21 & 4.47 & 5.42 & 6.51 & 7.59 & 8.90 & 10.12 \\
$\mathrm{Fe}_{2} \mathrm{O}_{3}$ & 0.03 & 0.03 & 0.05 & 0.06 & 0.09 & 0.13 & 0.17 & 0.19 & 0.20 \\
\hline
\end{tabular}
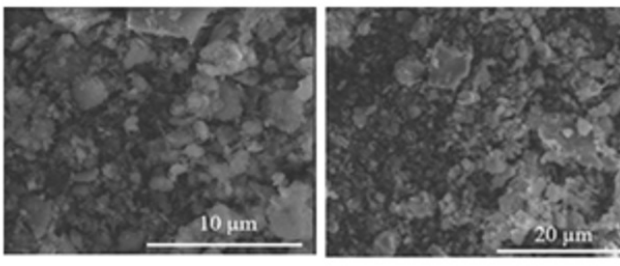

WS
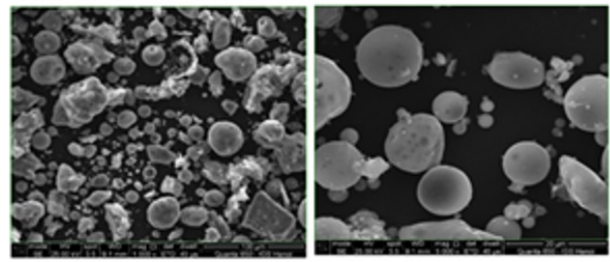

FA

Figure 2: SEM images of WS and FA

Physicomechanical properties of unbaked materials

Figure 3 showed the compressive strength of the samples under different curing conditions after 28 days of age.

The compressive strength of the test samples (Figure 3 ) under both curing conditions showed that the compressive strength of the 10\% FA and 40\% FA samples were higher than $3.5 \mathrm{MPa}$. The compressive strength of the $40 \%$ FA sample was higher than the $10 \%$ FA sample when the WG content was 6-8\%. However, with the 10-14\% WGs, the compressive strength of the $40 \%$ FA sample was lower than that of the $10 \%$ FA sample. The compressive strength of the 10\% FA and $10 \%$ WG samples was the highest. Therefore, the compressive strength, in this case, depends on the ability to form polymer bonding circuits in the tested samples. 

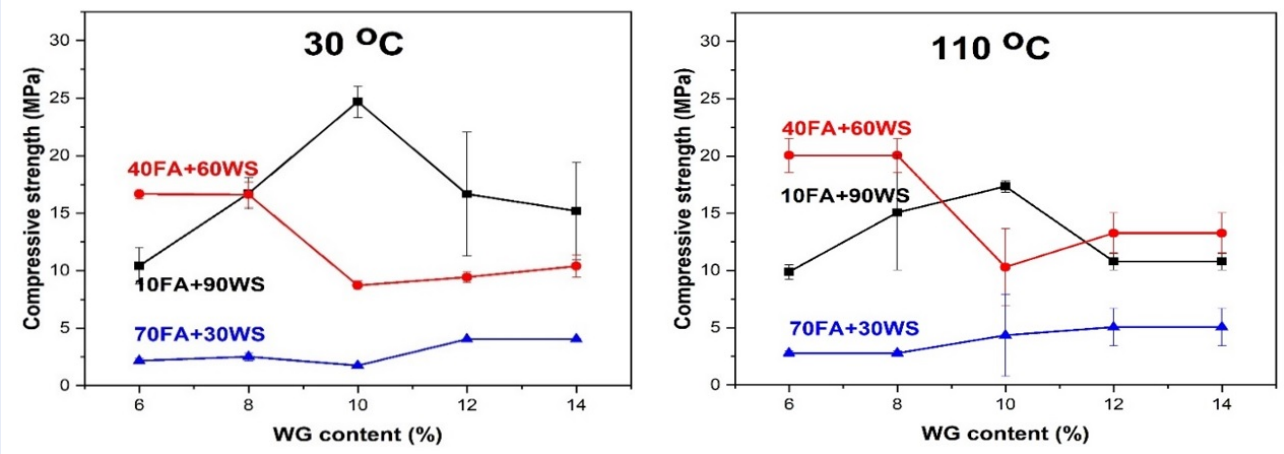

Figure 3: Compressive strength of the samples cured at $30^{\circ} \mathrm{C}$ (left) and at $110^{\circ} \mathrm{C}$ (right) after 28 days of age.
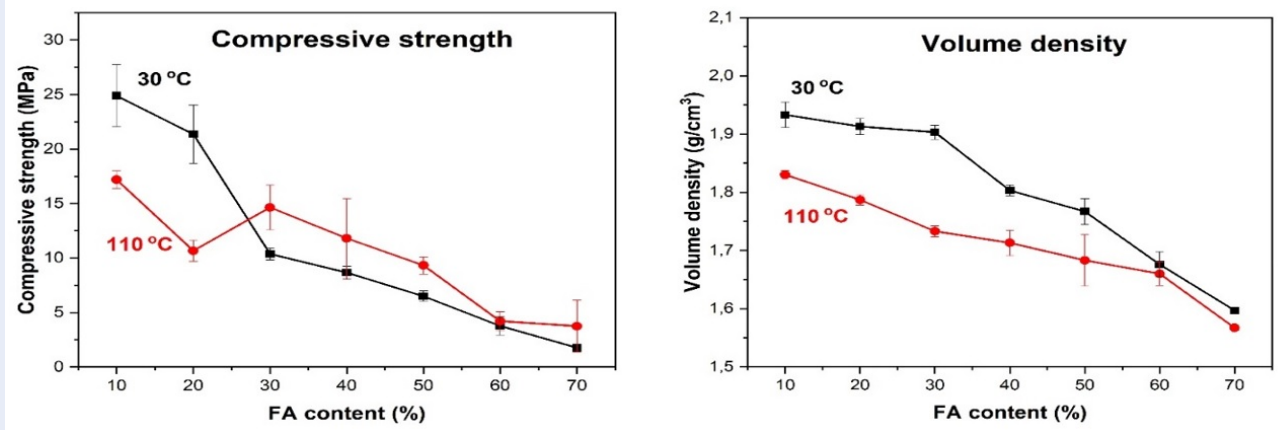

Figure 4: Influence of FA content to volumetric compressive strength (left) and volume density (right) of the $10 \%$ WG-containing samples

The volumetric density of the samples cured at room temperature was higher than that dried at $110^{\circ} \mathrm{C}$. The compressive strength of the samples cured at room temperature with a $10-20 \%$ FA content was also greater than that of the samples cured at $110^{\circ} \mathrm{C}$ (Figure 4). This result pointed out that the rate of water evaporation too fast did not increase the compressive strength.

\section{The change of pH according to curing time}

The $\mathrm{pH}$ changes of the samples according to curing time are plotted in Figure 5.

The plots of the $\mathrm{pH}$ change over curing time in Figure 5 indicated that the $\mathrm{pH}$ increased with an increase in the FA content. That can be explained by the higher $\mathrm{pH}$ of FA (11.5) than that of WS (7.5). Besides, the results also showed that the $\mathrm{pH}$ of the samples decreased over the curing time. The $10 \%$ FA sample at 28 days of age had the lowest $\mathrm{pH}$, such as the $\mathrm{pH}$ value of the $(10 \mathrm{FA}+90 \mathrm{WS})+10 \mathrm{WG}$ samples treated $110^{\circ} \mathrm{C}$ only is 9.1 (Figure 5). The $\mathrm{pH}$ value decreased over curing time because of the formation of a product layer on the surface, which prevents diffusion of $\mathrm{Na}^{+}$ions and the reaction of alkaline $\mathrm{NaOH}$ solution with $\mathrm{CO}_{2}$ in the air ${ }^{15,16}$ :

$$
2 \mathrm{NaOH}+\mathrm{CO}_{2} \rightarrow \mathrm{Na}_{2} \mathrm{CO}_{3}+\mathrm{H}_{2} \mathrm{O}
$$

\section{Analysis of bond formation by FTIR and mi- crostructure by SEM}

Figure 6 illustrate the FTIR spectra of raw material and $10 \%$ WG sample cured at $110^{\circ} \mathrm{C}$ for 28 days. Several characteristic bonds are indicated on these FTIR spectra.

On the FTIR spectrum of FA, the band in the 1033$538 \mathrm{~cm}^{-1}$ wavenumber corresponds to the oscillating region of the T-O-T bond ( $\mathrm{T}$ is the $\mathrm{Si}$ and $\mathrm{Al}$ tetrahedra) of the aluminosilicate minerals ${ }^{15,17,18}$. The band of 3441-3696 cm $\mathrm{cm}^{-1}$ corresponds to the oscillation of the $\mathrm{H}-\mathrm{O}-\mathrm{H}$ and $-\mathrm{OH}$ bond ${ }^{18}$. The band in the $469.2 \mathrm{~cm}^{-1}$ is characteristic of quartz ${ }^{12,19}$, and the band in the $2360 \mathrm{~cm}^{-1}$ corresponds to the oscillation of $\mathrm{CO}_{2}{ }^{15}$. The existence of $\mathrm{CO}_{2}$ groups on FTIR spectra is evidence of the possibility of reaction alkaline 

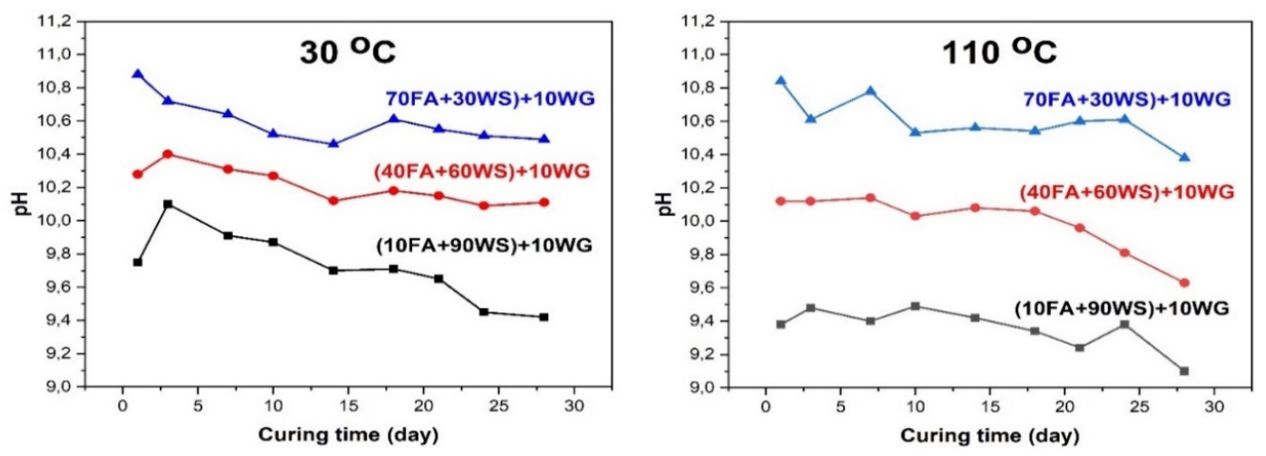

Figure 5: The $\mathrm{pH}$ changes according to curing time at $30^{\circ} \mathrm{C}$ (left) and at $110^{\circ} \mathrm{C}$ (right)

$\mathrm{NaOH}$ solution and $\mathrm{CO}_{2}$ in the air.

On the spectrum of WG, the band in the 3440-2700 $\mathrm{cm}^{-1}$ wavenumber region characterizes the $\mathrm{O}-\mathrm{H}$ oscillation of free water. On the FTIR spectra of the alkaline-activated samples, this band has narrowed. It is indicated that the dehydration was occurred in the geopolymer bond-forming process. The band in the $1569 \mathrm{~cm}^{-1}$ characterizes the $\mathrm{OH}^{-}$group in structure, and $1080 \mathrm{~cm}^{-1}$ characterizes the groups - $\mathrm{Si}$ - O $\mathrm{Si}$ - with bridging oxygens of the geopolymer materials $^{16,19}$.

Comparing the characteristic bands on the FTIR spectra of WS and $10 \%$ WG activated samples cured in a dryer at $110{ }^{\circ} \mathrm{C}$ indicated that they are almost identical. That means the weak activity of WS in the geopolymerization reaction. In other words, the WS acts as a filler. Meanwhile, the characteristic peaks on the FTIR spectra of the WG and FA changed very clearly: the range from 3440 to $2700 \mathrm{~cm}^{-1}$ on the WG spectrum no longer appears on the spectrum of all $10 \%$ activated samples. That are $(10 \mathrm{FA}+90 \mathrm{WS})+$ 10WG, $(40 \mathrm{FA}+60 \mathrm{WS}))+10 \mathrm{WG}$, and (70FA + 30WS) $+10 \mathrm{WG}$. Thus, the WG has lost water, condensed, and cured to form bonds in the material ${ }^{20}$. The characteristic peaks of the $\mathrm{Si}-\mathrm{O}-\mathrm{Si}$ bond at $1080 \mathrm{~cm}^{-1}$ on the WG spectrum shift to $950-980 \mathrm{~cm}^{-1}$ in the FTIR spectrum of $10 \%$ WG activated samples.

The microstructure of the samples investigated using the SEM. Figure 7 shows SEM images of WGactivated samples and WS-free samples under different curing conditions.

Comparing the SEM images of the WG-activated and WG-free samples in Figure 7 exhibits the roundshaped FA particles in the WG-activated sample completely deformed, almost participated in the geopolymerization reaction. The non-sphere fuzzy regions show the gel structure of the geopolymers that consisted of a WG-activated sample.

\section{CONCLUSIONS}

Unbaked materials can be fabricated from a mixture ( $40 \% \mathrm{FA}+60 \% \mathrm{WS}$ ) and $10 \% \mathrm{WG}$ by a relatively high forming pressure of $225 \mathrm{MPa}$. This material has the compressive strength $\mathrm{Rn}$ following the standard of unbaked material $(\mathrm{Rn}>3.5 \mathrm{MPa}$, according to Vietnamese Standards TCVN 6477: 2016). The $\mathrm{pH}$ of this material decreases with the time of storage and meets the National Technical Regulation QCVN 50: 2013 / BTNMT $^{13}$ on environmental impact. The geopolymer bonds in the material are formed mainly by WG condensation. The results suggest a new method of solidifying WS as aggregate for further applications such as fabrication of geopolymer concrete or fill material.

\section{ACKNOWLEDGEMENTS}

This research is funded by the Basic Science Research Program through Hochiminh City Department of Science and Technology under grant number 15/2019/HĐ-QPTKHCN. We acknowledge the support of time and facilities from Ho Chi Minh City University of Technology (HCMUT), VNU-HCM for this study.

\section{CONFLICT OF INTEREST}

The authors declare that there is no conflict of interest regarding the publication of this article.

\section{AUTHORS' CONTRIBUTION}

The contribution of each author in this article follows the State Council for Professorship. 


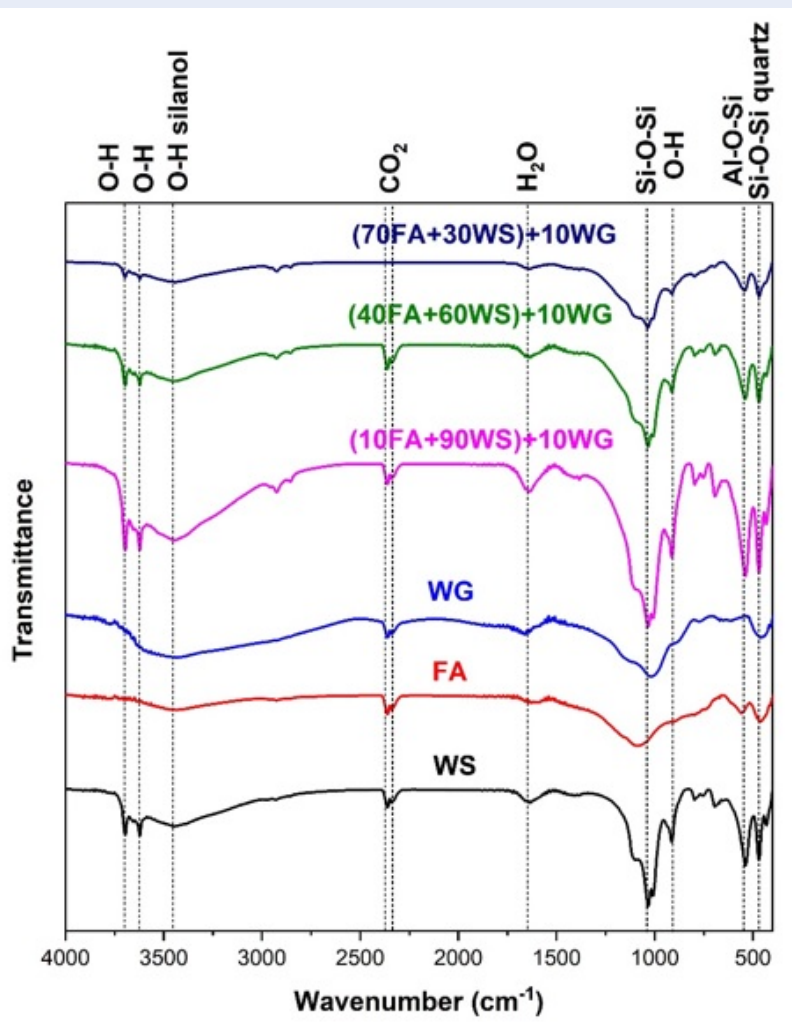

Figure 6: FTIR spectra of WS, FA, WG raw materials, and the $10 \%$ WG sample cured at $110^{\circ} \mathrm{C}$ for 28 days.

\section{REFERENCES}

1. Luukkonen T, Heponiemi A, Runtti H, Pesonen J, Yliniemi J, Lassi U. Application of alkali-activated materials for water and wastewater treatment: a review. Rev Environ Sci Biotechnol. 2019;18(2):271-297. Available from: https://doi.org/10.1007/ s11157-019-09494-0.

2. Gomes SDC, Zhou JL, Li W, Long G. Progress in manufacture and properties of construction materials incorporating water treatment sludge: A review, Resources, Conservation and Recycling. 2019;145:148-159. Available from: https://doi.org/10. 1016/j.resconrec.2019.02.032.

3. Onyelowe KC, et al. Recycling and reuse of solid wastes; a hub for ecofriendly, ecoefficient and sustainable soil, concrete, wastewater and pavement reengineering, Int J Low-Carbon Tech. 2019;14(3):440-451. Available from: https://doi.org/10. 1093/ijlct/ctz028.

4. Santos GZB, Filho JAM, Pinheiro M, Manzato L. Synthesis of water treatment sludge ash-based geopolymers in an Amazonian context. Journal of Environmental Management. 2019;249:109328. PMID: 31421479. Available from: https: //doi.org/10.1016/j.jenvman.2019.109328.

5. Suksiripattanapong C, Horpibulsuk S, Chanprasert P, Sukmak $P$, Arulrajah A. Compressive strength development in fly ash geopolymer masonry units manufactured from water treatment sludge, Construction and Building Materials. 2015;82:20-30. Available from: https://doi.org/10.1016/j. conbuildmat.2015.02.040.

6. Abdullah MMA, Nordin N, Tahir MFM, Kadir AA, Sandu AV. Potential of Sludge Waste Utilization as Construction Materials Via Geopolymerization. International Journal of Conservation Science. 2016;7(3):753-758.
7. Davidovits J. Chemistry of geopolymeric systems, terminology, in Proceedings of Geopolymer. International Conference, France. 1999;99:9-39.

8. Davidovits J. Geopolymers: Inorganic polymeric new materials, Journal of Thermal Analysis and Calorimetry. 1991;37(8):1633-1656. Available from: https://doi.org/10. 1007/BF01912193.

9. Vietnamese Standard, TCVN 7572: 2006-Aggregates for concrete and mortar - Test methods;

10. Le VQ, Do QM, Hoang MD, Nguyen HT. The role of active silica and alumina in geopolymerization. Vietnam Journal of Science, Technology and Engineering. 2018;60(2). Available from: https://doi.org/10.31276/VJSTE.60(2).16.

11. Do QM, Ngo PM, Nguyen HT. Characteristics of a Fly AshBased Geopolymer Cured in Microwave Oven, Key Engineering Materials (accessed Aug. 09, 2020). 2020;Available from: https://www.scientific.net/KEM.850.63.

12. Vietnamese Standard, TCVN 6477:2016-Concrete bricks;.

13. Vietnamese National Regulation. QCVN 50:2013/BTNMTNational Technical Regulation on Hazardous Thresholds for Sludges from Water Treatment Process;

14. D34 Committee. ASTM D3987-12(2020)-Practice for Shake Extraction of Solid Waste with Water, ASTM International. doi: 10.1520/D3987-12R20;Available from: https://doi.org/10. 1520/D3987-12R20.

15. Oh SY, et al. Crystalline structure analysis of cellulose treated with sodium hydroxide and carbon dioxide by means of $X$ ray diffraction and FTIR spectroscopy, Carbohydrate Research. 2005;340(15):2376-2391. PMID: 16153620. Available from: https://doi.org/10.1016/j.carres.2005.08.007.

16. Bobrowski A, et al. FTIR spectroscopy of water glass - the binder moulding modified by $\mathrm{ZnO}$ nanoparticles. Metalurgija. 2012;51(4):477-480. 

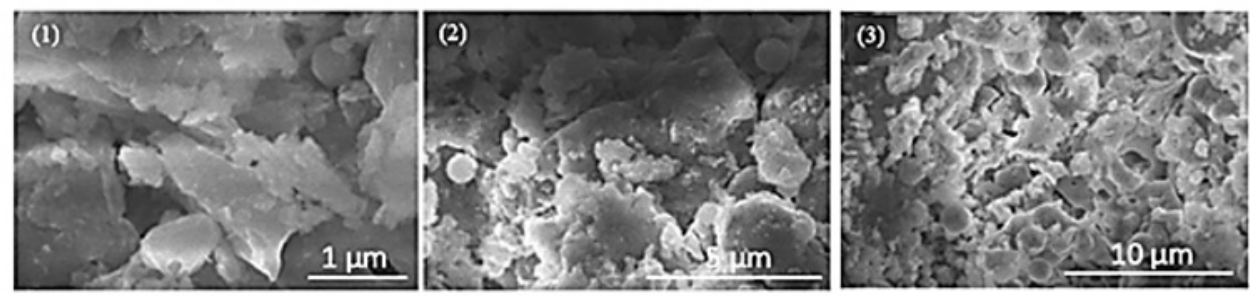

(a) (40FA+60WS) sample (without WG)
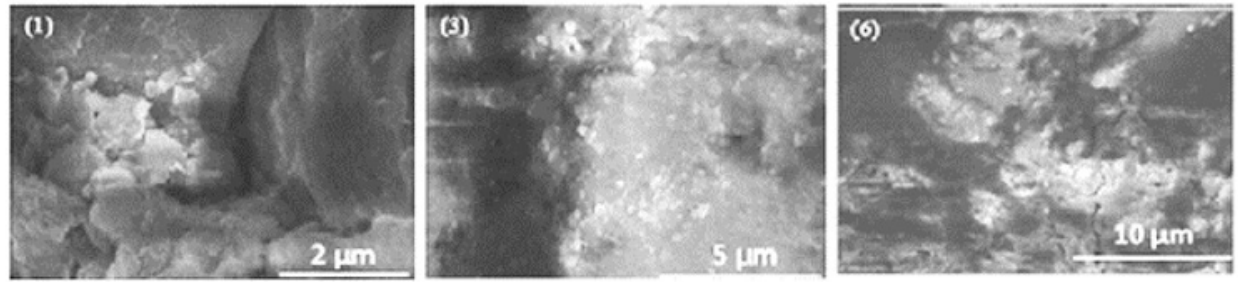

(b) $(40 \mathrm{FA}+60 \mathrm{WS})+10 \mathrm{WG}$ sample cured at $30^{\circ} \mathrm{C}$
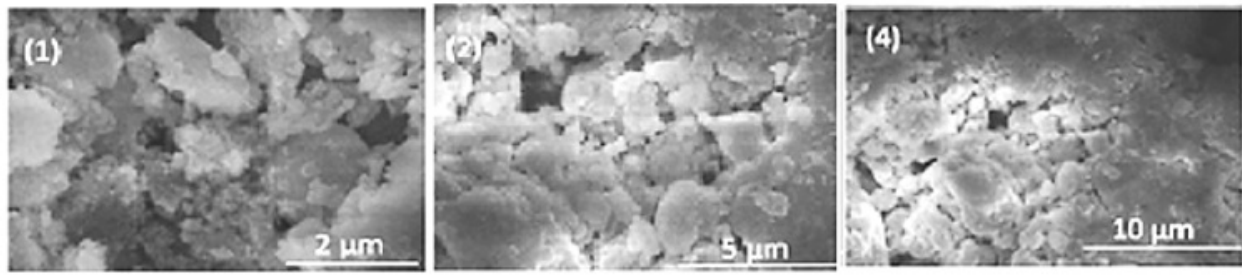

(c) $(40 \mathrm{FA}+60 \mathrm{WS})+10 \mathrm{WG}$ sample cured at $110^{\circ} \mathrm{C}$

Figure 7: SEM images of the (40FA+60WS) sample without WG and (40FA+60WS)+10WG sample cured at $30^{\circ} \mathrm{C}$ and at $110^{\circ} \mathrm{C}$

17. Marković SB, Dondur V, Dimitrijevic RM. FTIR spectroscopy of framework aluminosilicate structures: carnegieite and pure sodium nepheline. 2003;Available from: https://doi.org/10. 1016/S0022-2860(03)00249-7.

18. Young AM, Sherpa A, Pearson G, Schottlander B, Waters DN. Use of Raman spectroscopy in the characterisation of the acid-base reaction in glass-ionomer cements, Biomaterials. 2000;21(19):1971-1979. Available from: https://doi.org/10.
1016/S0142-9612(00)00081-8.

19. Nicholson JW. Chemistry of glass-ionomer cements: a review, Biomaterials. 1998;19(6):485-494. Available from: https://doi. org/10.1016/S0142-9612(97)00128-2.

20. Zhuang $X Y$, et al. Fly ash-based geopolymer: clean production, properties and applications. Journal of Cleaner Production. 2016;125:253-267. Available from: https://doi.org/10. 1016/j.jclepro.2016.03.019. 


\title{
Vật liệu không nung từ hỗn hợp bùn thải của nhà máy nước, tro bay và thủy tinh nước
}

\author{
Đỗ Quang Minh ${ }^{1,2}{ }^{*}$, Huỳnh Ngọc Minh ${ }^{1,2}$, Nguyễn Vũ Uyên Nhi ${ }^{1,2}$
}

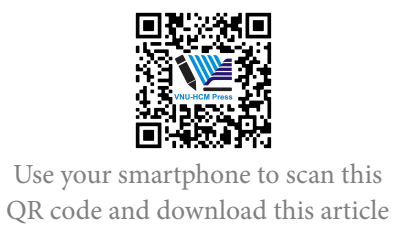

${ }^{1} B$ ộ môn Vật liệu Silicat, Khoa Công nghệ Vật liệu, Trương Đại học Bách Khoa Thành phố Hồ Chí Minh (HCMUT), 268 Lý Thường Kiêt, Quân 10, Thành phố Hồ Chí Minh, Việt Nam

${ }^{2} Đ a ̣ i$ học Quốc gia Thành phố Hồ Chí Minh, Phường Linh Trung, Quận Thủ Đức, Thành phố Hồ Chí Minh, Việt Nam

Liên hệ

Đỗ Quang Minh, Bộ môn Vật liệu Silicat, Khoa Công nghệ Vật liệu, Trường Đại học Bách Khoa Thành phố Hồ Chí Minh (HCMUT), 268 Lý Thường Kiệt, Quận 10, Thành phố Hồ Chí Minh, Việt Nam

Đại học Quốc gia Thành phố Hồ Chí Minh, Phường Linh Trung, Quận Thủ Đức, Thành phố Hồ Chí Minh, Việt Nam

Email: mnh_doquang@hcmut.edu.com

Lịch sử

- Ngày nhận: 10-8-2020

- Ngày chấp nhận: 27-01-2021

- Ngày đăng: 15-02-2021

DOI : 10.32508/stdjet.v4i1.754

\section{Check for updates}

\section{Bản quyền}

๑ ĐHQG Tp.HCM. Đây là bài báo công bố mở được phát hành theo các điều khoản của the Creative Commons Attribution 4.0 International license.

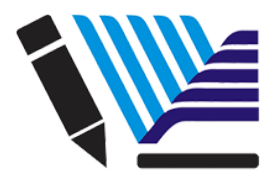

VNU-HCM Press

\section{TÓM TẮT}

Trong các nhà máy lọc nước, một phần lớn đất đô thị đang được sử dụng để chứa bùn thải (WS). Bùn thải từ các nhà máy lọc nước là alumino silicate, có thể tạo thành geopolymer. Tuy nhiên, bùn có hoạt tính kiềm thấp nên phải sử dụng kết hợp với tro bay (FA) để tạo sản phẩm geopolymer. Tro bay là chất thải rắn có chứa $\mathrm{SiO}_{2}$ vô định hình nên có hoạt tính kiểm cao, thích hợp để xử lý bằng phương pháp geopolymer. Quá trình tạo geopolymer hóa bùn thải từ các nhà máy lọc nước là một phương pháp tương đối mới. Geopolymer là chất kết dính được hình thành do phản ứng hóa học giữa vật liệu alumino silicate và dung dịch kích hoạt kiềm. Dung dịch kích hoạt kiềm được sử dụng trong các thí nghiệm này là thủy tinh nước (WG). Thủy tinh nước là dung dịch của natri silicate $\left(\mathrm{Na}_{2} \mathrm{O} . \mathrm{nSiO}_{2}\right)$ hòa tan trong nước. Kết quả nghiên cứu vật liệu geopolymer từ hỗn hợp tro bay, bùn thải của nhà máy lọc nước Thủ Đức, Thành phố Hồ Chí Minh (Việt Nam) và thủy tinh nước (WG) được giới thiệu trong nghiên cứu này. Các oxit $\mathrm{Al}_{2} \mathrm{O}_{3}$ và $\mathrm{SiO}_{2}$ hoạt tính trong tro bay và bùn thải có thể hòa tan trong thủy tinh nước và polyme hóa thành vật liệu geopolymer. Các mẫu thử nghiệm đã được ép ở áp suất cao $225 \mathrm{MPa}$ tạo thành những mầu hình trụ nặng khoảng $3 \mathrm{gam}$, chiều cao khoảng $18 \mathrm{~mm}$ và đường kính $10 \mathrm{~mm}$. Các mẫu này được bảo dưỡng ở $110^{\circ} \mathrm{C}$ trong 24 giờ và sau đó ở nhiệt độ phòng $\left(30 \pm 5^{\circ} \mathrm{C}\right)$. Các phương pháp quang phổ hồng ngoại Fourier (FTIR) và kính hiển vi điện tử quét (SEM) đã được sử dụng để phát hiện cấu trúc vi mô và sự hình thành liên kết geopolymer của mẫu. Cường độ nén của các mẫu thử nghiệm 28 ngày tuổi cao hơn $3,5 \mathrm{MPa}$, pH nhỏ hơn 12,5, đáp ứng Quy chuẩn quốc gia Việt Nam về vật liệu không nung (TCVN 6477: 2016) và Quy chuẩn kỹ thuật quốc gia về tác động môi trường (QCVN 50: 2013) / BTNMT), tương ứng. Kết quả cho thấy một cách tiếp cận mới trong việc hóa rắn bùn thải cho các ứng dụng khác như sản xuất bê tông geopolymer hoặc vật liệu san lấp.

Từ khoá: vật liệu không nung, tro bay (FA), bùn thải (WS), thủy tinh nước (WG), dung dịch hoạt tính kiềm, geopolymer
Trích dẫn bài báo này: Minh $\mathrm{D} Q$, Minh $\mathrm{H}$ N, Nhi N V U. Vật liệu không nung từ hỗn hợp bùn thải của nhà máy nước, tro bay và thủy tinh nước. Sci. Tech. Dev. J. - Eng. Tech.; 4(1):663-670. 